\title{
Experimental studies on the development of Contracaecum rudolphii (Nematoda: Anisakidae) in copepod and fish paratenic hosts
}

\author{
František Moravec
}

Institute of Parasitology, Biology Centre of the Academy of Sciences of the Czech Republic, Branišovská 31, 37005 České Budějovice, Czech Republic

\begin{abstract}
The larval development of the nematode Contracaecum rudolphii (Rudolphi, 1819), a common parasite of the proventriculus of cormorants, was experimentally studied. Within the eggs cultivated in freshwater under laboratory temperatures of $20-22{ }^{\circ} \mathrm{C}$, the developing larva undergoes two moults on days 4-5, attaining the third larval stage. Most of the ensheathed third-stage larvae, 291-457 $\mu \mathrm{m}$ long, hatch spontaneously from egg shells on days 5-6. Experiments have indicated that hatched ensheated third-stage larvae and those still inside egg capsules are already infective to copepods and fishes, which both can be considered paratenic (metaparatenic) hosts. Five copepod species, Acanthocyclops vernalis, Cyclops strenuus, Ectocyclops phaleratus, Eucyclops serrulatus and Megacyclops viridis, the isopod Asellus aquaticus and small carps Cyprinus carpio were infected by feeding them these larvae. In addition, 9 fish species, Alburnoides bipunctatus, Anguilla anguilla, Barbatula barbatula, Cyprinus carpio, Gobio gobio, Perca fluviatilis, Phoxinus phoxinus, Poecilia reticulata and Tinca tinca, were successfully infected by feeding them copepods previously infected with C. rudolphii third-stage larvae. In fishes, larvae from copepods penetrate through the intestinal wall to the body cavity, where, in a few weeks, they become encapsulated; the larvae substantially grow in fish, attaining the body length up to $4.87 \mathrm{~mm}$. In carp fry, the nematode third-stage larvae survived for about 15 months (up to 18 months in fish infected directly, i.e., without copepods). One small cormorant (Phalacrocorax carbo sinensis) was successfully infected by feeding it with copepods harbouring C. rudolphii third-stage larvae.
\end{abstract}

Key words: parasitic nematode, Contracaecum, cormorant, Phalacrocorax, development, paratenic host, copepod, fish, Czech Republic

In older literature, the species of Contracaecum Railliet et Henry, 1912 (Nematoda, Anisakidae) parasitizing mostly cormorants was incorrectly reported under the name C. spiculigerum (Rudolphi, 1809). However, according to Hartwich (1964), who examined the type specimens of the latter originating from Pelecanus onocrotalus Linnaeus and deposited in the Zoological Museum Berlin, C. spiculigerum is a junior synonym of Contracaecum microcephalum (Rudolphi, 1809). Therefore, he established C. rudolphii Hartwich, 1964 for the species from cormorants.

Until recently, C. rudolphii (s.1.) was considered a cosmopolitan parasite of cormorants and some other piscivorous birds (e.g., Hartwich 1964, Moravec et al. 1988, Bartlett 1996, Nottenkämper et al. 1999, Torres et al. 2000, 2005, Żuchowska 2000, Baruš et al. 2001, Barson and Marshall 2004, Kanarek and Rokicki 2005, Amato et al. 2006). However, recent genetic studies have indicated that $C$. rudolphii is a species complex consisting of several, not yet formally established sibling species (Mattiucci et al. 2002, D'Amelio et al. 2007, Farjallah et al. 2008). According to Mattiucci et al. (2002), colonies of the great cormorant Phalacrocorax carbo sinensis (Blumenbach) living in freshwater environments in central Europe are parasitized by nematodes belonging to the taxonomic unit provisionally designated as $C$. rudolphii $\mathrm{B}$; molecular support for this contention is presented by Szostakowska and Fagerholm (2007) identifying only C. rudolphii B in fishes from freshwaters in Poland. The specimens from cormorants from the Czech Republic were sent to Prof. Lia Paggi, Rome, who confirmed their belonging to C. rudolphii B.

The life cycle of C. rudolphii is not well known. Moreover, observations on the development of this nematode in North America by Thomas (1937a,b), Huizinga (1966) (both reporting it as C. spiculigerum) and Bartlett (1996), all based on specimens from the double-crescent cormorant Phalacrocorax auritus (Lesson), apparently concern a different Contracaecum species, which was provisionally designated C. rudolphii C by D'Amelio et al. (2007). 
In Russia (Krasnodarskiy Kray) and Azerbaijan, the life cycle of $C$. rudolphii (under the designation C. spiculigerum) was studied by Mozgovoy et al. (1965, 1968). They observed only one larval moult inside the egg shell and considered copepods of the genera Cyclops Müller and Macrocyclops Claus to be intermediate hosts, dragonfly larvae (Agrion Fabricius, Coenagrion Kirby) either as second intermediate hosts or paratenic hosts, and fishes as second intermediate or paratenic hosts; they successfully infected cormorants by feeding them C. rudolphii larvae from experimentally infected dragonflies. Previously Dubinin (1949) obtained adult specimens of C. rudolphii (as C. spiculigerum) by feeding the larvae from naturally infected fishes [Rutilus rutilus (L.) and Silurus glanis L.] to cormorants and pelicans. Experimental infections of unidentified copepods and amphipods with C. rudolphii larvae have recently been carried out by Dziekońska-Rynko and Rokicki (2007) in north-eastern Poland, who observed two larval moults inside the egg shell and considered cyclopoid copepods and amphipods to be paratenic hosts. Nevertheless, in their later paper, the same authors (Dziekońska-Rynko and Rokicki 2008) considered the larvae of C. rudolphii hatched from eggs to be the second-stage larvae. They used these larvae for the successful experimental infection of Carassius auratus (Linnaeus), in which C. rudolphii larvae occurred in the intestinal wall and the body cavity up to five weeks after exposure to free larvae, but no larvae were found in the fish examined in subsequent weeks.

In 1989-1992, during studies on the helminth fauna of the great cormorant, Phalacrocorax carbo sinensis, in the Czech Republic, several experiments to elucidate the development of C. rudolphii were carried out. The results obtained are presented in this paper.

\section{MATERIALS AND METHODS}

The nematodes Contracaecum rudolphii were recovered from the proventriculus of great cormorants, Phalacrocorax carbo sinensis, shot around nest colonies in South Bohemia (ponds near Třeboň) and South Moravia (ponds near Pohořelice and water reservoir Nové Mlýny), Czech Republic in the period from April to September. The gravid female nematodes containing large numbers of fully mature eggs were placed individually in small Petri dishes (diameter 5-6 cm) filled with freshwater, their bodies were torn by fine needles and the eggs were released from the uteri; the eggs were cultivated in water in Petri dishes at the laboratory temperatures of $20-22^{\circ} \mathrm{C}$. Feeding experiments with copepods were made in larger Petri dishes (diameter 16$19 \mathrm{~cm}$ ) filled with water. Each dish contained a few hundreds of copepods to which different quantities (usually about one thousand) of parasite's eggs containing fully formed larvae and hatched free larvae were added. Cyclopid copepods Acanthocyclops vernalis (Fischer), Cyclops strenuus Fischer, Ectocyclops phaleratus (Koch), Eucyclops serrulatus (Fischer) and Megacyclops viridis (Jurine) originating mostly from a few ponds near České Budějovice, South Bohemia, were used. These were kept at the laboratory temperatures of $20-22^{\circ} \mathrm{C}$. They were fed with
Paramecium Müller and examined each day. Small numbers of the aquatic isopod Asellus aquaticus L., the amphipod Gammarus fossarum Koch and the ostracod Notodromas monacha Müller were also used for experimental infection. Nematode larvae were fixed so that they were immobilized by heating them in a drop of water on a glass slide over a flame for several seconds and a drop of $4 \%$ formaldehyde solution was added. Ultimately, the killed larvae were examined with a light microscope.

Feeding experiments with fishes were carried out in small aquaria in the laboratory where fishes were either allowed to feed spontaneously on the infected copepods harbouring the parasite's third-stage larvae or the copepods were forced to fishes using a stomach tube. Then the experimental fishes were fed with tubificids and commercial pellet food and they were examined at different intervals. The following 13 fish species were used: 36 guppies, Poecilia reticulata Peters (body length 2-4 cm) from a laboratory culture; 53 common carps, Cyprinus carpio L. (4-12 cm) from fish hatchery; and the following species of a different origin: 2 asps, Aspius aspius (L.) $(5-6 \mathrm{~cm})$; 2 bleaks, Alburnus alburnus (L.) $(11 \mathrm{~cm}) ; 3$ spirlins, Alburnoides bipunctatus (Bloch) (7-11 cm); 2 roaches, Rutilus rutilus (L.) $(12 \mathrm{~cm}) ; 1$ European chub, Leuciscus cephalus (L.) $(12 \mathrm{~cm})$; 4 gudgeons, Gobio gobio (L.) $(8-11 \mathrm{~cm}) ; 3$ Eurasian minnows, Phoxinus phoxinus (L.) $(5 \mathrm{~cm}) ; 4$ tenches, Tinca tinca (L.) $(9-10 \mathrm{~cm}) ; 3$ stone loaches, Barbatula barbatula $(\mathrm{L}).(9-11 \mathrm{~cm})$, 9 European perches, Perca fluviatilis L. $(7-10 \mathrm{~cm})$ and 5 European eels, Anguilla anguilla (L.) (about $10 \mathrm{~cm}$ ). In addition, 4 northern pikes, Esox lucius L. (19-28 cm) and 2 Perca fluviatilis $(18-19 \mathrm{~cm})$ were fed with the carp fry previously infected with $C$. rudolphii larvae. Two small specimens of cormorants (P. carbo sinensis) (weight about $330 \mathrm{~g}, 3$ weeks old) used in experiments were hatched experimentally from eggs and fed cooked fish flesh.

The nematode specimens from fishes were fixed in hot $4 \%$ formaldehyde solution and cleared in glycerine for light microscopy. Drawings were made with the aid of a Zeiss microscope drawing attachment. All measurements are in micrometres unless otherwise stated.

\section{RESULTS}

\section{Egg and larval development}

The eggs of $C$. rudolphii were irregularly oval to spherical, size $66-72 \times 60-66$, with almost smooth surface. The hyaline wall of the egg shell appeared to be bilayered, about 3 thick. When laid, the egg content was mostly cleaved into 2 or 4 blastomeres, less often it was unsegmented or already at the morula stage (Fig. 1 A-D). A small micropyle was present (Fig. 1 A,D). After $24 \mathrm{hrs}$ at water temperature of $20-22^{\circ} \mathrm{C}$, many eggs contained a somewhat motile tadpole stage with a broad anterior end and a blunt posterior end. Two days after the start of egg cultivation, most eggs already contained fully formed first-stage larvae; on the next day, these underwent their first moult and changed into second-stage larvae.

The second-stage larvae (Fig. $1 \mathrm{H}$ ) expressed from egg shells 3 days after establishment of the culture were 444 516 long and 18-21 wide, their lighter-coloured part was 120-180 long, the distance of the nerve ring from the an- 

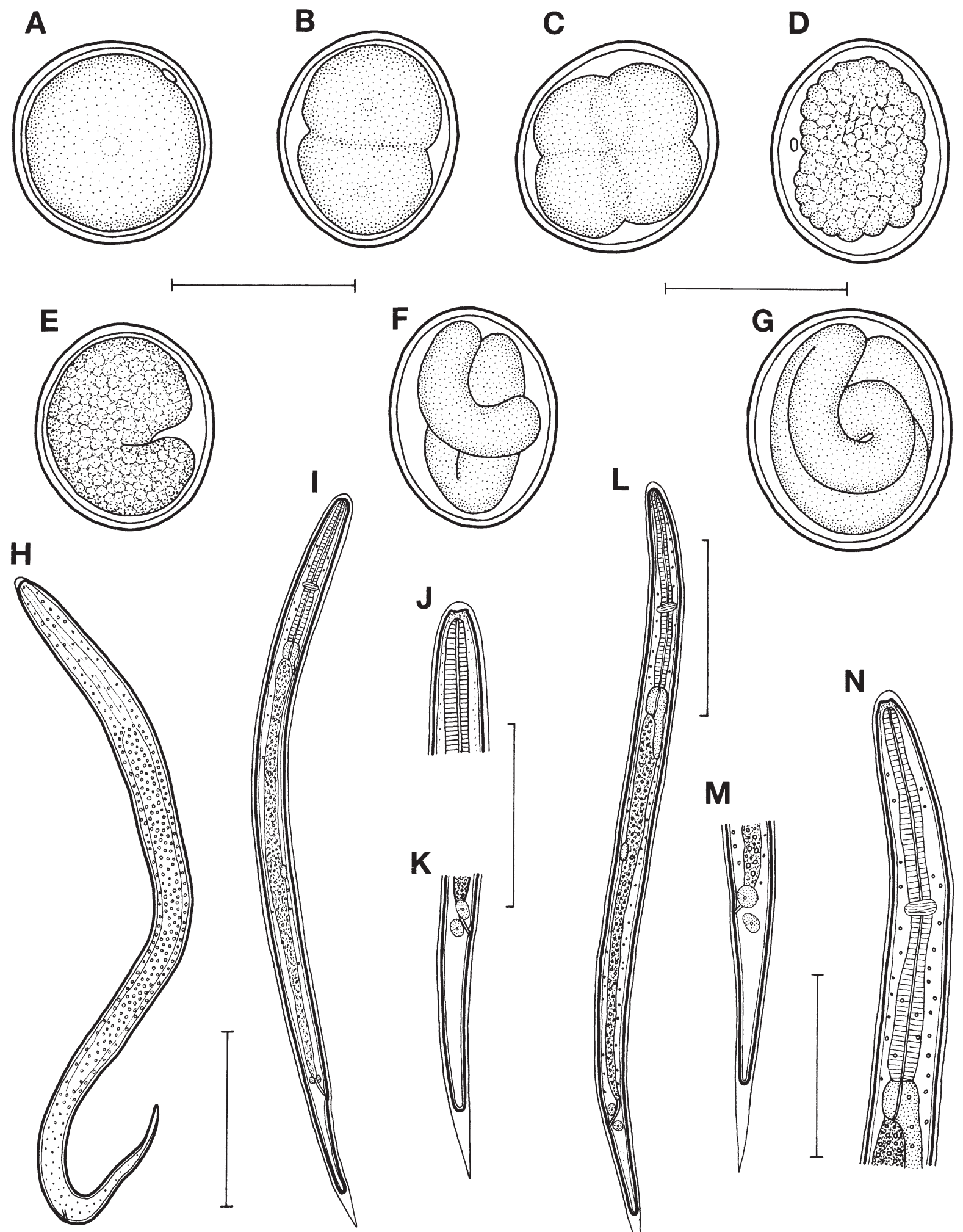

Fig. 1. Contracaecum rudolphii Hartwich, 1964, development of larvae in eggs. A-D - eggs at different states of development (formation of morula) after 1 day of cultivation (laboratory temperature); $\mathbf{E}, \mathbf{F}-$ eggs after 3 days of cultivation (formation of larva); $\mathbf{G}$ - egg containing fully formed third-stage larva after 7 days of cultivation; $\mathbf{H}$ - second-stage larva starting second moult, expressed from egg after 2 days of cultivation; $\mathbf{I}-\mathbf{K}$ - third-stage larva still inside shed cuticle of second moult, expressed from egg after 7 days of cultivation (I - general view, J - cephalic end, $\mathrm{K}$ - caudal end); $\mathbf{L}-\mathbf{N}$ - same, another specimen with more developed ventricular appendix. Scale bars: A-G, J, K, M, N $=50 \mu \mathrm{m} ; \mathrm{H}, \mathrm{I}, \mathrm{L}=100 \mu \mathrm{m}$. 
terior extremity was 57-75, and the length of the tail (including its cuticular sheath) was $87-120$. Their body was slender, with a blunt anterior end and a conical posterior end. Almost the whole body was densely granulated, the granulation being densest in mid-body, somewhat scarce in the oesophageal region, and practically absent from the anterior and posterior ends of the larva. These larvae immediately started the second moult, so that the loosen second-stage cuticle could be seen on both larval body ends. The larvae were rotating actively within the egg shells.

The second larval moult was completed 4-5 days after the establishment of egg culture, but the motile thirdstage larvae remained inside the shed cuticle of the second stage (Fig. $1 \mathrm{I}-\mathrm{N}$ ). Most of the third-stage larvae hatched spontaneously on days 5-6. However, the speed of the larval development was not the same in all eggs and not all third-stage larvae hatched but remained inside egg shells.

The hatched third-stage larvae (Fig. 2 A) were still inside the cuticular sheath of the second moult; their body including the old shed cuticle was 423-435 long, its maximum width was $18-21$. The proper third-stage larva was 291-457 long and 15-18 wide. The body was light-coloured, with a very fine, dense transverse striation of the cuticle. The cephalic end was provided with a distinct dorsal larval tooth 3 long; the tail was 39-45 long, with a rounded tip. The oesophagus was light-coloured, not well visible, 87-96 long, encircled by the nerve ring located 51-57 from the anterior extremity. The small, thin-walled ventriculus was 9 long and 9-12 wide, the ventricular appendix was poorly developed, short. The intestine was filled with numerous small brownish granules; no intestinal caecum was present. A small oval genital primordium located postequatorially on the ventral side was visible in some larvae. The hatched larvae did not swim in water but they attached by their tail tip to the bottom of the vessel, coiling and straightening their body intensively, thus presumably stimulating predation by copepods. Apparently, the free larvae live for relatively short time in water, this being dependent on the temperature.

\section{Experimental infection of invertebrates}

In order to clarify questions on the possible intermediate or paratenic hosts of $C$. rudolphii, cyclopid copepods belonging to five species and some other aquatic invertebrates were exposed to free third-stage larvae and eggs containing third-stage larvae. For these experiments, undetermined large numbers of copepods (Acanthocyclops vernalis, Cyclops strenuus, Ectocyclops phaleratus, Eucyclops serrulatus, Megacyclops viridis), 50 ostracods (Notodromas monacha), 20 amphipods (Gammarus fossarum) and 20 isopods (Asellus aquaticus) were used.

However, all specimens of $N$. monacha and those of G. fossarum died 3 days after possible infection and they
Table 1. Direct infections of Cyprinus carpio with Contracaecum rudolphii third-stage larvae.

\begin{tabular}{cccc}
\hline Fish Nos. Days p.i. & $\begin{array}{c}\text { No. of larvae } \\
\text { found }\end{array}$ & Localisation \\
\hline $1-3$ & 1 & not examined & - \\
4 & 21 & 225 & free in liver and intestine \\
5 & 149 & 0 & - \\
6 & 538 & 19 & $\begin{array}{c}\text { encapsulated on surface } \\
\text { of liver and intestine }\end{array}$ \\
7 & 553 & 10 & $\begin{array}{c}\text { encapsulated on intestinal surface } \\
\text { encapsulated mainly on surface of } \\
\text { intestine, liver and gall-bladder } \\
8\end{array}$ \\
566 & 97 & - \\
9 & 604 & 0 & \\
\hline
\end{tabular}

were not examined. The remaining 18 live specimens of A. aquaticus were examined on day 10 p.i., but only a single, still ensheathed small C. rudolphii third-stage larva was found free in the gut of one of them. Probably this larva survived long in water and was only recently swallowed by the isopod.

Free ensheated third-stage larvae were readily ingested by copepods. Within 30 minutes, it was possible to observe many larvae in the gut lumen of many experimental crustaceans. All copepod species were successfully infected and the percentage of infected copepods in individual experiments was frequently $100 \%$, with the intensity of infection 1-30 larvae per crustacean; the highest intensities were recorded in $M$. viridis 10 days p.i. (30 larvae) and $A$. vernalis 12 days p.i. (22 larvae). However, during the first few days after infection, usually a high rate of mortality of infected copepods was observed.

When the larvae of $C$. rudolphii were ingested by a copepod, these penetrated through the wall of the copepod's digestive tract to its haemocoel within a few hours. During this penetration, undoubtedly accomplished with the aid of the larval cephalic tooth, the third-stage larvae lost their cuticular sheath from the second moult. The larvae in copepods were followed for the period of 12 days p.i., when the remaining infected copepods were used for feeding experiments with fishes. As compared with free third-stage larvae, the larvae from copepods 12 days p.i. were of approximately the same size or only slightly larger. These were 435-450 long, their maximum width was $14-18$. The cephalic tooth was 3 long. The oesophagus measured 120-126, the nerve ring was located 75-78 from the anterior extremity. The ventriculus was 12 long and 12 wide; however, the ventricular appendix was already well developed, 51-78 long, whereas the intestinal caecum was missing. The tail was $39-45$ long. The genital primordium was located 171-213 from the posterior extremity. No moult of larvae in copepods was observed. The larvae were freely moving in the copepod's haemocoel of the cephalothorax, frequently remained spirally coiled, but never encapsulated. 


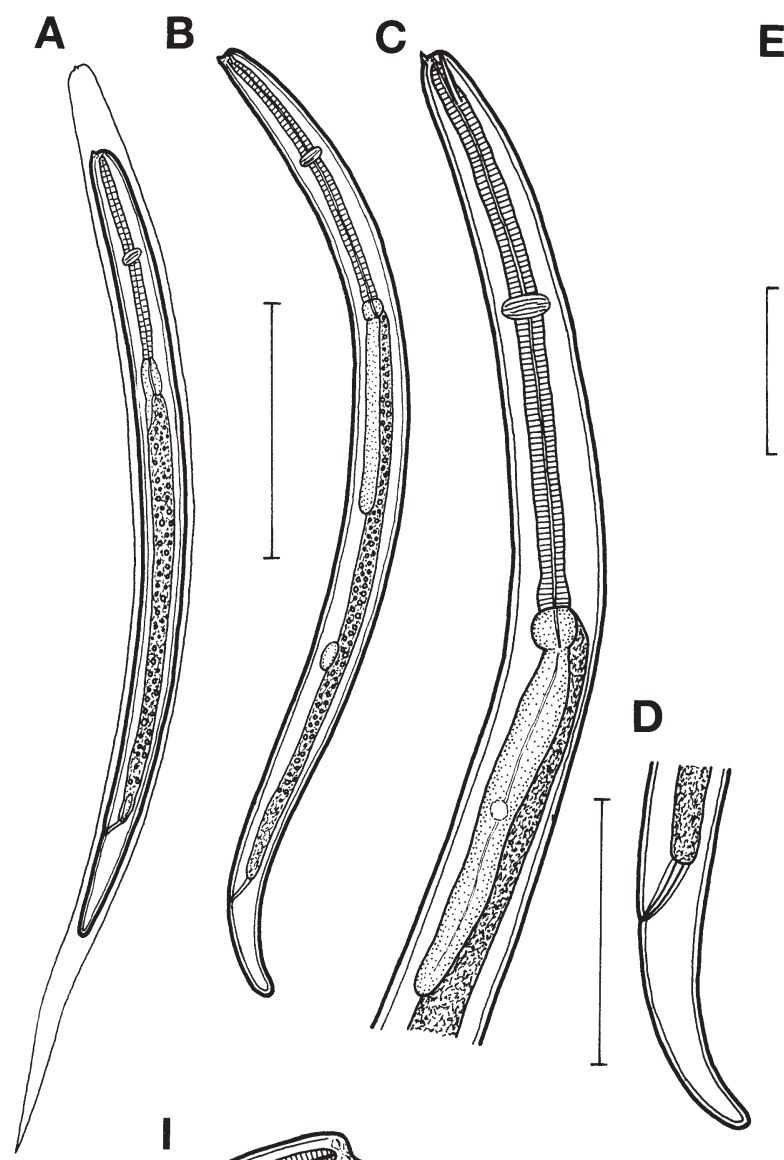

E

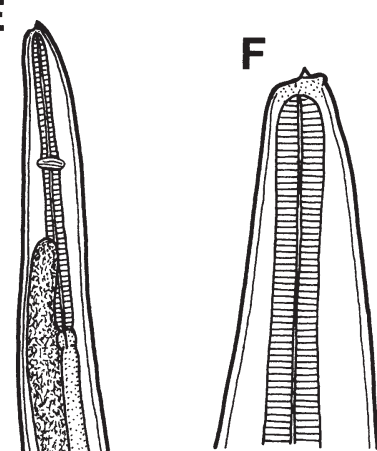

G

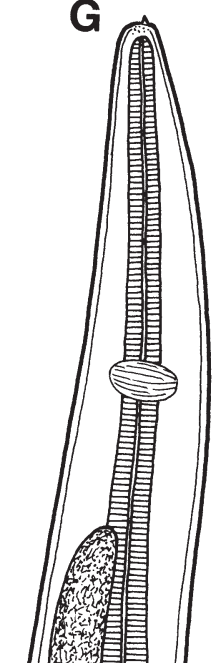

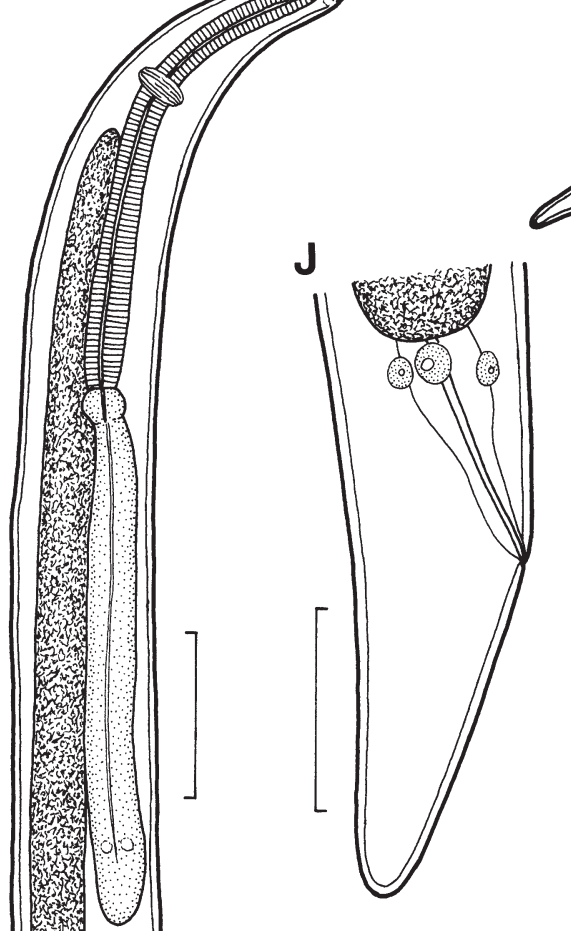

$\mathbf{K}$

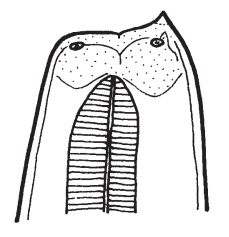

$\mathbf{H}$

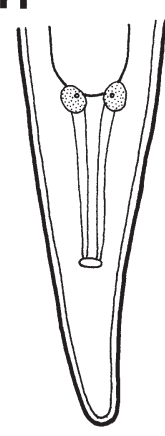

$\mathbf{L}$

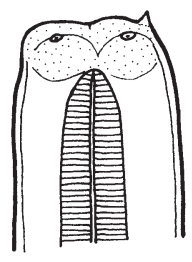

Fig. 2. Contracaecum rudolphii Hartwich, 1964, third-stage larvae. A - larva (still in shed cuticle of second moult) newly hatched from egg shell, general view; B-D - larva from copepod paratenic host 12 days p.i. (B - general view, C - anterior end, D - tail); E-H - larva from fish paratenic host 49 days p.i. (E - general view, F - cephalic end, G - anterior part of body, H - tail, ventral view); I-L - larvae from fish paratenic host 60 days p.i. (I - anterior part of body, J - tail, K, L - cephalic ends). (A-D from Ectocyclops phaleratus, E-L - from Cyprinus carpio fry.) Scale bars: A, B, E, I = $100 \mu \mathrm{m} ; \mathrm{C}, \mathrm{D}, \mathrm{G}, \mathrm{H}, \mathrm{J}=50 \mu \mathrm{m} ; \mathrm{F}, \mathrm{K}, \mathrm{L}=30 \mu \mathrm{m}$. 


\section{Experimental infection of fishes}

\section{a) Direct infections with third-stage larvae:}

To elucidate the question whether fishes may acquire C. rudolphii infection directly by ingestion the third-stage larvae and to determine thus the actual role of copepods in the life cycle of this parasite, a large number of the nematode ensheated third-stage larvae (both hatched and still inside egg capsules) were forced with a pipette into the stomach of each of 9 small specimens (fry) of carp (C. carpio) (see Table 1). Subsequently, 3 carps escaped from the experimental tank and died 1 day p.i. and these were not examined. One carp (7.5 cm long) examined 21 days p.i. harboured a total of 225 larvae freely moving mainly in the liver (about two thirds of larvae) and in the intestine; the larvae seemed to be mostly only slightly larger than the third-stage larvae hatched from eggs, but some of them were distinctly larger. Of the remaining 5 experimental carps examined at different intervals, 3 (examined on days 538, 553 and 566) proved to be infected with 10-97 larvae encapsulated in the body cavity, mainly on the surface of the liver and intestine; 2 carps were found free of infection (Table 1).

The third-stage larvae obtained from carps on days 538 and 553 were $3.97-4.87 \mathrm{~mm}$ long, with a maximum width of 177-245. Their cuticle was roughly transversely striated, striation being best visible on the middle part of the body. The cephalic end was provided with a well developed ventral larval tooth. The oesophagus was 476-525 long, being encircled by the nerve ring at 171-219 from the anterior extremity. The ventriculus measured $27-36 \times$ 24-36; the length of the ventricular appendix was 449 552, that of the caecum 294-318. The intestine was broad, brown-coloured. The tail was conical, 90-120 long, with a rounded tip. Small oval genital primordium was situated ventrally some distance posterior to the distal end of the ventricular appendix.

These experiments clearly show that a direct infection of fishes with free third-stage larvae is possible and that copepods do not serve as intermediate hosts for C. rudolphii, but act only as paratenic hosts. They also indicate that the larvae in fishes substantially grow (without an additional moult) and become encapsulated after a few months; they can survive in fish for nearly two years (at least 18 months).

\section{b) Infections with third-stage larvae from copepods:}

To determine a susceptibility of different fish species to C. rudolphii infection, to follow the larval development of this parasite in fish paratenic hosts, and to demonstrate the parasite's transmission to fish via infected copepods, several feeding experiments were carried out. A total of 116 specimens of fishes belonging to 13 species, representing 5 fish families (Anguillidae, Balitoridae, Cyprinidae,
Table 2. Survey of fishes infected with Contracaecum rudolphii larvae via copepods.

\begin{tabular}{|c|c|c|c|c|}
\hline Fish species & $\begin{array}{c}\text { No. of } \\
\text { specimens } \\
\text { in exper./ } \\
\text { infected }\end{array}$ & Intensity & $\begin{array}{c}\text { Days p.i. } \\
\text { (infected fish) }\end{array}$ & $\begin{array}{l}\text { Localisa- } \\
\text { tion }\end{array}$ \\
\hline Poecilia reticulata & $36 / 7$ & $\begin{array}{c}4-90 \\
(\text { mean 25) }\end{array}$ & \multirow{2}{*}{\multicolumn{2}{|c|}{$\begin{array}{c}49,65,70,73 \text {, mesentery, } \\
87,103,122 \text { fat tissue } \\
14,20,24 \text { intestine, } \\
48,49,60 \text {, liver, } \\
82,115,254, \text { mesentery } \\
419,425,442\end{array}$}} \\
\hline Cyprinus carpio & $44 / 13$ & $\begin{array}{c}1-600 \\
\text { (mean 106) }\end{array}$ & & \\
\hline Aspius aspius & $2 / 0$ & - & - & - \\
\hline Alburnus alburnus & $2 / 0$ & - & - & - \\
\hline $\begin{array}{l}\text { Alburnoides } \\
\text { bipunctatus }\end{array}$ & $3 / 1$ & 2 & 74 & intestine \\
\hline Rutilus rutilus & $2 / 0$ & - & - & - \\
\hline Leuciscus cephalus & $1 / 0$ & - & - & - \\
\hline Gobio gobio & $4 / 1$ & 1 & 47 & intestine \\
\hline Phoxinus phoxinus & $3 / 2$ & 6,128 & 10,87 & intestine \\
\hline Tinca tinca & $4 / 4$ & $\begin{array}{c}1-127 \\
\text { (mean 49) }\end{array}$ & $18,23,27,32$ & $\begin{array}{l}\text { intestine, } \\
\text { mesentery }\end{array}$ \\
\hline Barbatula barbatula & $3 / 3$ & $\begin{array}{c}4-95 \\
(\text { mean } 61)\end{array}$ & $7,10,52$ & intestine \\
\hline Perca fluviatilis & $7 / 3$ & $1-6($ mean 3$)$ & 2,3 & intestine \\
\hline Anguilla anguilla & $5 / 1$ & 17 & 24 & intestine \\
\hline
\end{tabular}

Percidae and Poeciliidae), was employed in these experiments (Table 2). Of them, 9 species were successfully infected with C. rudolphii larvae: Alburnoides bipunctatus, Anguilla anguilla, Barbatula barbatula, Cyprinus carpio, Gobio gobio, Perca fluviatilis, Phoxinus phoxinus, Poecilia reticulata, and Tinca tinca. However, this does not mean that the non-infected species are unsuitable paratenic hosts for this nematode; negative results were probably only due to low numbers of available specimens, fish mortality and some experimental errors.

The experimental fishes were fed with different numbers of copepods previously infected with C. rudolphii third-stage larvae (see above); the copepods were infected 7-12 days before being fed to fishes. Then the experimental fishes were examined by a thorough helminthological dissection at different intervals.

After ingestion of copepods, the C. rudolphii larvae remained for some time (up to a few weeks) free in the fish intestinal lumen and only then they penetrated through the intestinal wall into the body cavity, locating on the surface of the intestine and liver and in the mesenteries. The larvae gradually increased in size, attaining the body length of about $2-2.5 \mathrm{~mm}$ in 2 months p.i., but their morphology remained the same and no moult was observed in them. At that time, the larvae mostly remained irregularly coiled or with a bent anterior end, and their body became encapsulated by a thin membraneous cover. The larvae were observed to survive for about 15 months in carp fry and for about 4 months in guppies. The intensities of infection were frequently high; the highest degree of infection (about 600 larvae) was recorded in a carp with the body length of $13 \mathrm{~cm}$, examined 419 days p.i. 


\section{c) Infections with third-stage larvae from fishes:}

To determine whether the C. rudolphii larvae parasitic in fishes can migrate to the organism of a piscivorous fish in a case of predation or cannibalism, the following experiment was performed: Each of 4 pikes, E. lucius (body length 16-28 cm), and 2 perches, P. fluviatilis (18 and $19 \mathrm{~cm}$ ), were fed with small carps (about $4 \mathrm{~cm}$ long) presumed to be infected with $C$. rudolphii third-stage larvae; each fish was given 3 carps, except for 1 perch, which received only 2 carps. The carps were previously ( 74 days before the start of this experiment) infected via infected copepods; 10 control carps examined were all infected, with the intensity $1-186$ (mean 33 ) nematode larvae. All these experimental pikes and perches were examined 16 days p.i., but none of them was found infected. This indicates that a migration of these larvae from one fish host to another is probably impossible.

\section{Experimental infection of cormorants}

Two young cormorants, both laboratory cultured from eggs, were fed with many experimentally infected copepods in May 1992. Each cormorant was fed with copepods harbouring altogether ca. 50 larvae 7 or 12 days p.i. Both cormorants were thoroughly examined 3 days later. Whereas the first bird was found uninfected, the second one harboured one C. rudolphii third-stage larva 571 long and 41 wide in the mucosa of its proventriculus. Compared with larvae from copepods, the larva in the cormorant slightly increased in size. This confirms that the definitive host (cormorant) of C. rudolphii can be infected not only through infected fishes, but also the larvae from copepods may be infective to this bird host.

\section{DISCUSSION}

Although the life cycle of Contracaecum rudolphii (earlier under the synonym $C$. spiculigerum) was experimentally studied by a few authors in North America (Thomas 1937a,b, Huizinga 1966, Bartlett 1996) and Europe (Mozgovoy et al. 1965, 1968, Dziekońska-Rynko and Rokicki 2007), their observations considerably differ from each other mainly in the evaluation of the role played by different animal groups in the cycle. Whereas Thomas (1937a) observed two larval moults inside the egg shell of this parasite and considered the hatched larvae to be at the third stage, Mozgovoy et al. (1965, 1968), Huizinga (1966) and Bartlett (1996) observed only one moult within the egg and took the hatched larvae for the secondstage larvae. The data by Thomas (1937a) concerning the two moults of larvae in the egg of C. rudolphii has recently been confirmed by Dziekońska-Rynko and Rokicki (2007), as well as by the results of the present paper. This pattern of moulting is also found in other anisakid nematodes, such as Contracaecum osculatum (Rudolphi, 1802), Hysterothylacium aduncum (Rudolphi, 1802), Ani- sakis simplex (Rudolphi, 1809) or Pseudoterranova decipiens (Krabbe, 1878) (see Køie 1993, Køie and Fagerholm 1993, 1995, Køie et al. 1995, Adroher et al. 2004).

Thomas (1937a) demonstrated that the hatched thirdstage larvae are already infective to fish hosts by exposing 30 guppies ( $P$. reticulata) to free-living larvae in small dishes; 1-2 days later, he found that only 3 of them were infected with free larvae located mostly in the intestine and rarely in the body cavity. Huizinga (1966) considered the hatched larvae to be only partly infective to fish that ingested them directly, because only 1 of 200 guppies exposed to these larvae harboured 3 larvae in the mesentery 16 days p.i. Similar results were obtained by Bartlett (1996), who had successfully infected 3 guppies of 6 exposed to newly hatched larvae, but none of 27 Fundulus heteroclitus L. used in the same experiment. As mentioned above, recently Dziekońska-Rynko and Rokicki (2008) successfully infected Carassius auratus by exposing them to $C$. rudolphii larvae hatched from eggs; the larvae were present in fish during the first five weeks after exposure, but they were not found in them in subsequent weeks. However, the above data are contrasting with the results of our experiments, where small carps were easily infected directly by $C$. rudolphii hatched larvae, sometimes with high intensities of infection, and the third-stage larvae, considerably increased in size and encapsulated in the body cavity, survived for 19 months (Table 1). This shows that the third-stage larvae of this parasite, either hatched or still inside the egg shells, are fully infective to fish hosts.

Mozgovoy et al. $(1965,1968)$ were the first who paid attention to the role of cyclopid copepods in the life cycle of C. rudolphii. They noted that the larvae slightly increased in size in copepods and, although they did not record any moult, they considered the larvae from copepods to represent third-stage larvae. Consequently, they took copepods for the obligate intermediate hosts of C. rudolphii. Huizinga (1966) and Bartlett (1996) also observed a slight growth, but no moult, of larvae in copepods, considering them second-stage larvae. While Huizinga (1966) considered copepods to be transport (= paratenic) hosts, Bartlett (1996) designated them as "precursor hosts", emphasizing their possible role as a source of infection for amphipods. Our study clearly shows, as previously indicated by Thomas (1937a), Huizinga (1966) and Bartlett (1996), that copepods are not obligatory for the development of C. rudolphii and, therefore, serve only as paratenic hosts (see also Dziekońska-Rynko and Rokicki 2004); because the larvae increase in size in copepods, the latter may be designated metaparatenic hosts (Odening 1976).

Mozgovoy et al. $(1965,1968)$ successfully infected predatory nymphs of aquatic insects (Odonata) with C. rudolphii third-stage larvae by feeding them experimentally infected copepods; because later they used these infected dragonflies for successful experimental infection of two 
young cormorants, these insects were considered to be the second intermediate hosts, as also the fish fry previously infected via infected copepods. The fish (T. tinca) infected by feeding them infected dragonflies were designated as paratenic hosts by Mozgovoy et al. $(1965,1968)$. Experimentally infected copepods were also used by Bartlett (1996) for the successful infection of experimental amphipods. It is apparent from the present study that none of the above mentioned hosts (i.e., predatory insects, amphipods, fish fry, tench) infected via infected copepods is quite necessary for the development of C. rudolphii and, therefore, they are also only paratenic hosts.

The development and morphogenesis of C. rudolphii larvae in fishes experimentally infected via infected copepods was followed only by Huizinga (1966) and Bartlett (1996) in Poecilia reticulata and Fundulus heteroclitus in North America; the maximum body length of larvae recorded from the latter host was $1.9 \mathrm{~mm}$ on day 18 p.i., that of the former was $3.9 \mathrm{~mm}$ on day 152 p.i. In contrast, in our experiments, 5 fish species (4 native and 1 exotic) were successfully infected and the larval development in carps infected either via copepods or directly by free-living larvae was followed for the period of about 15 months (442 days) or 18 months (553 days), respectively; the maximum recorded body length of larvae was $4.87 \mathrm{~mm}$. Huizinga (1966) mentioned that on day 18, a moult of larvae $1.2 \mathrm{~mm}$ long in fish was in progress and he classified them as ensheated third stage (he considered larvae from copepods to be second-stage larvae). Even though Bartlett (1966) could not confirm the moult of larvae in infected fish, she considered larger larvae from fish as third-stage larvae (those from copepods as second-stage larvae) and, consequently, she took fishes for the intermediate hosts of C. rudolphii. However, it is apparent from the results of this paper that fishes, although the most important source of C. rudolphii infection for cormorants, are not quite necessary for completing the parasite's life cycle and they evidently serve only as paratenic (metaparatenic) hosts.

Thomas (1937a) successfully infected Micropterus salmoides (Lacépède) by feeding them parasitized guppies; 1-3 days p.i. he found in them several small C. ru- dolphii larvae (averaged $353 \mu \mathrm{m}$ in length) in the intestine and a single larva $1.117 \mathrm{~mm}$ long encapsulated in the mesenteries; no infection was recorded in M. salmoides 13 days p.i. In contrast, our attempts to infect predatory fishes (pikes, perches) by feeding them small carps harbouring encapsulated $C$. rudolphii larvae (74 days p.i.) gave negative results. This indicates that only very small parasite's larvae are capable of migration from one fish host to another during predation, whereas such migration is no longer possible in larger, encapsulated larvae.

Although attempts to experimentally infect cormorants with infected fishes by Mozgovoy et al. (1965, 1968) were unsuccessful, it was previously proved by Dubinin's (1949) feeding experiments that infected fishes are the main source of $C$. rudolphii infection for cormorants. However, as apparent from the present paper, cormorants can also be infected via copepods harbouring small parasite's third-stage larvae. This indicates that probably already free third-stage larvae are infective for cormorants. Consequently, as indicated by present data and those by Mozgovoy et al. $(1965,1968)$, the life cycle of C. rudolphii is direct (homoxenous), without an obligate intermediate host. Aquatic invertebrates (mainly copepods and some other crustaceans, insects) and fishes harbouring infective third-stage larvae serve only as paratenic hosts of C. rudolphii, but they seem to be obligate in the parasite's life cycle from an ecological viewpoint. Apparently, after cormorants acquire $C$. rudolphii infection mainly by feeding on infected fish, the larvae of the parasite undergo two more moults in the digestive tract of this bird definitive host before they attain maturity.

Acknowledgements. The author is indebted to J. Ondra, former State Fishery Pohořelice, and J. Schönbauer, former State Fishery Třeboň, for providing cormorants. Thanks are also due to $\mathrm{V}$. Našincová, T. Scholz, I. Husáková, M. Valešová and J. Borovka, Institute of Parasitology ASCR, for their technical assistance. This work was supported by the grant No. 62211 of the Academy of Sciences of the Czech Republic and by the research projects of the Institute of Parasitology, BC ASCR (Z60220518 and LC522).

\section{REFERENCES}

Adroher F.J., Malagyn D., Valero A., Benitez R. 2004: In vitro development of the fish parasite Hysterothylacium aduncum from the third larval stage recovered from a host to the third larval stage hatched from the egg. Dis. Aquat. Org. 58: 41-45.

Amato J.F.R., Monteiro C.M., Аmato S.B. 2006: Contracaecum rudolphii Hartwich (Nematoda, Anisakidae) from the Neotropical cormorant, Phalacrocorax brasilianus (Gmelin) (Aves, Phalacrocoracidae) in southern Brazil. Rev. Brasil. Zool. 23: 1284-1289.

Barson M., Marshall B.E. 2004: First record of Contracaecum spp. (Nematoda: Anisakidae) in fish-eating birds from Zimbabwe. J. S. Afr. Vet. Assoc. 75: 1-5.

BARTlett C.M. 1996: Morphogenesis of Contracaecum rudolphii (Nematoda: Ascaridoidea), a parasite of fish-eating birds, in its copepod precursor and fish intermediate hosts. Parasite 4: $367-376$.

Baruš V., Tenora F., Kráčmar S., Prokeš M. 2001: Cadmium and lead concentrations in Contracaecum rudolphii (Nematoda) and its host, the cormorant Phalacrocorax carbo (Aves). Folia Parasitol. 48: 77-78.

D’Amelio S., Barros N.B., Ingrosso S., Fauquier D.A., Russo R., PAGgi L. 2007: Genetic characterization of members of the genus Contracaecum (Nematoda: Anisakidae) from fish-eating birds from west-central Florida, USA, with evidence of new species. Parasitology 134: 1041-1051.

Dubinin V.B. 1949: [Experimental study of the life cycles of some parasitic worms of animals in the Volga River delta.] Parazitol. Sb., Zool. Inst. Akad. Nauk SSSR, 11: 126-160. (In Russian.) 
Dziekońska-Rynko J., Rokicki J. 2007: Experimental infestation of copepods and amphipods with Contracaecum rudolphii larvae. In: C.M. Nigmatullin (Ed.), Proceedings of the IV AllRussian Workshop on Theoretical and Marine Parasitology, AtlantNIRO Publishing, Kaliningrad, pp. 58-60.

Dziekońska-Rynko J., Rokicki J. 2008: Experimental infection of Carassius auratus (L., 1758) with the second stage larvae of the nematode Contracaecum rudolphii Hartwich, 1964. Wiad. Parazytol. 54: 339-343.

Farjallah S., Merella P., Ingrosso S., Rotta A., Ben Slimane B., Garippa G., Said K., Busi M. 2008: Molecular evidence for the occurrence of Contracaecum rudolphii A (Nematoda: Anisakidae) in shag Phalacrocorax aristotelis (Linnaeus) (Aves: Phalacrocoracidae) from Sardinia (western Mediterranean Sea). Parasitol. Int. 57: 437-440.

Hartwich G. 1964: Revision der vogelparasitischen Nematoden Mitteleuropas II. Die Gattung Contracaecum Railliet \& Henry, 1912 (Ascaridoidea). Mitt. Zool. Mus. Berl. 40: 15-53.

Huizinga H.W. 1966: Studies on the life cycle and development of Contracaecum spiculigerum (Rudolphi, 1809) (Ascaroidea: Heterocheilidae) from marine piscivorous birds. J. Elisha Mitchell Sci. Soc. 82: 181-195.

KANAREK G., Rokicki J. 2005: The status of studies on the helminth fauna of the great cormorant (Phalacrocorax carbo sinensis) in northern Poland. Wiad. Parazytol. 51: 165.

KøIE M. 1993: Aspects of the life cycle and morphology of Hysterothylacium aduncum (Rudolphi, 1802) (Nematoda, Ascaridoidea, Anisakidae). Can. J. Zool. 71: 1289-1296.

Køie M., Berland B., Burt M.D.B. 1995: Development to third stage larvae occurs in the eggs of Anisakis simplex and Pseudoterranova decipiens (Nematoda, Ascaroidea, Anisakidae). Can. J. Fish. Aquat. Sci. 52: 134-139.

Køie M., Fagerholm H.-P. 1993: Third-stage larvae emerge from eggs of Contracaecum osculatum (Nematoda, Anisakidae). J. Parasitol. 79: 777-780.

Køie M., Fagerholm H.-P. 1995: The life cycle of Contracaecum osculatum (Rudolphi, 1802) sensu stricto (Nematoda, Ascaridoidea, Anisakidae) in view of experimental infections. Parasitol. Res. 81: 481-489.

Mattiucci S., Turchetto M., Bragantini F., Nascetti G. 2002: On the occurrence of the sibling species of Contracaecum rudolphii complex (Nematoda: Anisakidae) in cormorants (Phalacro-

Received 22 April 2009 corax carbo sinensis) from Venice and Caorle lagoons: genetic markers and ecological studies. Parassitologia 44: 105.

Moravec F., Našincová V., Scholz T. 1988: New records of helminth parasites from cormorants (Phalacrocorax carbo (L.)) in Czechoslovakia. Folia Parasitol. 35: 381-383.

Mozgovoy A.A., Shakhmatova V.I., Semenova M.K. 1965: [Study of the life cycle of Contracaecum spiculigerum (Ascaridata: Anisakidae), a nematode of fish-eating birds.] Materials of the Scientific Conference of the All-Union Society of Parasitologists, Pt. 4, pp. 169-174. (In Russian.)

Mozgovoy A.A., Shakhmatova V.I., Semenova M.K. 1968: [Life cycle of Contracaecum spiculigerum (Ascaridata: Anisakidae), a parasite of domestic and game birds.] Tr. GELAN 19: 129136. (In Russian.)

Nottenkämper D., Korbel R., Kösters J. 1999: Zum Befall von Kormoranen (Phalacrocorax carbo sinensis L., 1758) mit Contracaecum rudolphii (Nematoda: Ascaridoidea) im Bezirk Oberbayern (D) und Kanton St. Gallen (CH). Tierärztl. Prax. 27: 274-279.

Odening K. 1976: Conception and terminology of hosts in parasitology. Adv. Parasitol. 14: 1-93.

Szostakowska B., Fagerholm H.-P. 2007: Molecular identification of two strains of third-stage larvae of Contracaecum rudolphii sensu lato (Nematoda: Anisakidae) from fishes in Poland. J. Parasitol. 93: 961-964.

Thomas L.J. 1937a: On the life cycle of Contracaecum spiculigerum (Rud.). J. Parasitol. 23: 429-431.

Thомаs L.J. 1937b: Further studies on the life cycle of Contracaecum spiculigerum. J. Parasitol. 23: 572.

Torres P., Ortega J., Schlatter R. 2005: Nematode parasites of the digestive tract in Neotropical cormorant chicks (Phalacrocorax brasilianus) from the River Cruces Ramsar site in southern Chile. Parasitol. Res. 97: 103-107.

Torres P., Valdivieso J., Schlatter R., Montefusco A., Revenga J., Marín F., Lamilla J., Ramallo G. 2000: Infection by Contracaecum rudolphii (Nematoda: Anisakidae) in the Neotropical cormorant Phalacrocorax brasilianus, and fishes from the estuary of the Valdivia river, Chile. Stud. Neotrop. Fauna Environ. 35: 101-108.

Żuchowska E. 2000: Contracaecum rudolphii Hartwich, 1964 (Nematoda: Anisakidae) u kormoranów w Polsce. Wiad. Parazytol. 46: 411-412.

Accepted 22 June 2009 